\title{
PERANCANGAN APLIKASI KUIS INTERAKTIF BERBASIS ANDROID SEBAGAI MEDIA PEMBELAJARAN PADA MATA PELAJARAN TEKNOLOGI INFORMASI \& KOMUNIKASI DI KELAS X SMA PLUS NURUL ILMI CIBALONG
}

\author{
Rosi Aprilia Utami ${ }^{1)}$, Cecep Riki ${ }^{2)}$, Alfadl Habibie ${ }^{3)}$ \\ ${ }^{1)}$ Pendidikan Teknologi Informasi FKIP Universitas Muhammadiyah Tasikmalaya \\ Email: rosiapriliautami@gmail.com ${ }^{1)}$, cecep.riki.74@gmail.com, Alfadl@umtas.ac.id ${ }^{3)}$
}

\begin{abstract}
Abstraksi
Berdasarkan hasil pra penelitian, diketahui bahwa di SMA Plus Nurul Ilmi terdapat adanya keterbatasan media pembelajaran pada mata pelajaran Teknologi informasi \& Komunikasi, keterbatasan Modul TIK, keterbatasn Laboratorium Komputer dan juga waktu belajar pada mata pelajaran Teknologi Informasi \& Komunikasi. Penelitian ini bertujuan untuk membuat suatu perancangan aplikasi kuis berbasis Android dengan menggunakan aplikasi Ispring suite $v$ 9.7. Metode penelitian ini menggunakan ADDIE (Analysis, Design, Development, Implementation dan Evaluation). Berdasarkan hasil penelitian, maka diperoleh hasil bahwa aplikasi kuis ini terdiri dari aspek kesesuaian materi, Design dan kemudahan dalam pengunaannya. Hasil Uji kelayakan media pembelajaran kuis interaktif dari penelitian ini yaitu "Layak digunakan" bagi peserta didik kelas X di SMA Plus Nurul Ilmi. Hal ini bisa dilihat dari hasil presentase Ahli media sebesar 79,41\%, dari Tenaga pendidik 79,07\% dan dari Peserta didik 66,60\% berkriteria baik.
\end{abstract}

Kata Kunci: Media Pembelajaran, Teknologi Informasi dan Komunikasi, Aplikasi Kuis interaktif, ADDIE.

\begin{abstract}
Based on the results of pre-research, it is known that in SMA Plus Nurul Ilmi there are limitations of learning media in the subjects of Information Technology \& Communication, limitations of ICT Modules, limited computer laboratory and also study time in subjects of Information Technology \& Communication. The research aims to create an Android-based quiz app design using the Ispring suite v 9.7 app.This research method uses ADDIE (Analysis, Design, Development, Implementation and Evaluation).Based on the results of the research, the results obtained that this quiz application consists of aspects of material suitability, design and ease in its use.The results of the interactive quiz learning media due diligence from this study are "Worth using" for X-grade students at SMA Plus Nurul Ilmi.This can be seen from the results of the media expert percentage of $79.41 \%$, from educators $79.07 \%$ and from students $66.60 \%$ in good criteria.
\end{abstract}

Keywords: Learning Media, Information Technology and Communication, Interactive Quiz App, ADDIE.

\section{PENDAHULUAN}

Teknologi memang sangat tergolong penting dalam bidang pendidikan untuk itu di sekolah di adakan mata pelajaran TIK (Teknologi Informasi dan Komunikasi) supaya para peserta didik berkemajuan apalagi sekarang berada di Era Revolusi Industri 4.0 yaitu merupakan fenomena yang mengkolaborasikan teknologi cyber dan teknologi otomatisasi. Konsep penerapannya berpusat pada konsep otomatisasi yang dilakukan oleh teknologi tanpa memerlukan tenaga kerja manusia dalam proses Implementasinya, untuk itu mata pelajaran TIK (Teknologi Informasi dan Komunikasi) begitu penting untuk dipelajari supaya tidak ketinggalan zaman yang setiap tahunnya selalu ada kemajuan terutama di bidang Teknologi. Namun tidak sedikit peserta didik yang belum paham terhadap Teknologi hal ini dilihat dari nilai dan pengetahuan mengenai mata pelajaran Teknologi Informasi dan Komunikasi (TIK) pada raport peserta didik, karena faktor kurang minatnya peserta didik terhadap mata pelajaran TIK (Teknologi Informasi dan komunikasi) ataupun sedikitnya waktu atau jadwal yang diberikan untuk belajar mata 
pelajaran TIK (Teknologi Informasi dan komunikasi), untuk itu perlu adanya pendorong untuk menambah pengetahuan peserta didik khususnya dibidang teknologi.

Permasalahan yang didapat dalam penelitian ini merupakan adanya keterbatasan dalam media pembelajaran peserta didik dan keterbatasan waktu belajar dalam mata pelajaran TIK (Teknologi Informasi dan komunikasi) maka peneliti membuat Aplikasi Kuis untuk mata pelajaran TIK (Teknologi Informasi dan Komunikasi) Agar peserta didik bisa belajar mata pelajaran TIK di manapun berada, Berdasarkan perumusan masalah penelitian yang telah dijelaskan, maka didapat tujuan penelitian ini adalah Menghasilkan perancangan dan media pembelajaran Aplikasi Kuis interaktif berbasis Android pada mata pelajaran TIK (Teknologi Informasi dan Komunikasi). Untuk mengetahui tingkat kelayakan Aplikasi Kuis berbasis Android pada mata pelajaran TIK (Teknologi Informasi dan Komunikasi) yang akan digunakan oleh peserta didik kelas X di SMA Plus Nurul Ilmi Cibalong.

Batasan masalah pada penelitian ini materi soal kuis dibatasi, hanya membahas mengenai mata pelajaran TIK (Teknologi Informasi dan Komunikasi) Aplikasi ini bisa digunakan dari mulai vesi Android 1.0 (2008) ke atas. Aplikasi ini digunakan secara offline, yaitu dapat dijalankan tanpa menggunakan sambungan internet. Aplikasi ini dibuat Berbasis Android dan nantinya terinstall di Handphone para peserta didik kelas X SMA Plus Nurul Ilmi, aplikasi kuis ini dibuat juga sekaligus untuk menjadi contoh penerapan di bidang teknologi informasi.

\section{A. Perancangan Aplikasi}

Perancangan aplikasi merupakan tahapan awal ataupun rancangan yang nantinya di lanjutkan ke tahap penyusunan aplikasi dengan memasukan kode program kemudian hasil akhirnya berupa aplikasi dengan berbasis Android. Konsep perancangan aplikasi merupakan aplikasi kuis yang akan dibuat. Untuk dapat merancang konsep dalam membuat aplikasi kuis dibutuhkan pemahaman terhadap mata pelajaran yang bersangkutan, juga dibutuhkan kreatifitas pada saat pembuatan aplikasi kuis. Kreatifitas adalah kemampuan untuk menyajikan gagasan atau ide baru bagaimana menciptakan aplikasi kuis yang layak digunakan, user friendly dan memiliki design yang menarik.

\section{B. Kuis Interaktif}

Kuis interaktif tergolong sebagai media pembelajaran berbasis computer, sebagaimana dikemukakan oleh Arsyad (2011:100) bahwa kuis interaktif dapat digolongkan menjadi media pembelajaran berbasis teknologi karena dalam proses penggunaannya dibutuhkan computer ataupun handphone. Kuis interaktif merupakan sebuah aplikasi yang berisi materi pelajaran dalam bentuk soal atau pertanyaan yang memungkinkan peserta didik untuk meningkatkan wawasan dan pengetahuannya mengenai materi pelajaran secara mandiri [2]

Kuis dapat menambah wawasan dan meningkatkan kemampuan siswa tentang materi pelajaran yang saat itu sedang dipelajarinya. Kuis juga dapata merangsang siswa untuk belajar. Suryadi (2007:92) mengatakan bahwa penggunaan teknologi dalam proses pembelajaran akan menimbulkan rasa senang karena siswa berinteraksi dengan gambar, video, maupun animasi. Kondisi rasa senang inilah yang menjadi faktor penting dalam efektifitas belajar [9].

\section{Android}

Android merupakan System operasi yang banyak digunakan pada perangkat bergerak yang dewasa ini sangat terkenal dan populer digunakan pada ponsel cerdas. Android juga merupakan platform pemrograman yang dikembangkan oleh google untuk ponsel cerdas dan perangkat selular lainnya, misalnya tablet. Android bisa berjalan dibeberapa macam perangkat yang dikembangkan oleh banyak vendor ponsel cerdas yang berbeda. Android menyertakan paket pengembangan perangkat lunak untuk penulisan kode asli dan perakitan modul perangkat lunak dalam membuat aplikasi bagi pengembang Android. Selain menyediakan paket pengembangan aplikasi android, android juga menyediakan pasar untuk mendistribusikan aplikasi yang telah selesai dikembangkan. Dengan lengkapnya fasilitas yang disediakan oleh android dapat dikatakan bahwa keseluruhan Android menciptakan ekosistem sendiri [5].

\section{Media Pembelajaran}

Media berasal dari bahasa latin merupakan bentuk jamak dari "Medium" yang secara harfiah berarti "Perantara" atau "Pengantar" yaitu perantara atau pengantar sumber pesan dengan penerima pesan. Beberapa ahli memberikan definisi tentang media pembelajaran. National Education Associaton (1969) mengungkapkan bahwa media pembelajaran adalah sarana komunikasi dalam bentuk cetak maupun pandang-dengar, termasuk teknologi perangkat keras. Dapat disimpulkan bahwa media pembelajaran adalah segala sesuatu yang dapat menyalurkan pesan, dapat merangsang fikiran, perasaan, dan kemauan peserta didik sehingga dapat mendorong terciptanya proses belajar pada diri peserta didik [6].

Pada mulanya, media pembelajaran hanya berfungsi sebagai alat bantu guru untuk mengajar yang digunakan adalah alat bantu visual. Sekitar pertengahan abad ke-20 usaha pemanfaatan visual dilengkapi dengan digunakannya 
alat audio, sehingga lahirlah alat bantu audio-visual. Sejalan dengan perkembangan ilmu pengetahuan dan teknologi (IPTEK), khususnya dalam bidang pendidikan, saat ini penggunaan alat bantu atau media pembelajaran menjadi semakin luas dan interaktif, seperti adanya komputer dan internet.

\section{METODE PENELITIAN}

Metode penelitian yang digunakan dalam penelitian ini adalah ADDIE (Analysis, Design, Development, Implementasi, Evaluasi) ADDIE adalah model perancangan instruksional yang berupa proses umum yang secara tradisional digunakan oleh perancang instruksional ataupun pengembangan pelatihan. Model ADDIE merupakan inti perancangan instruksional dan menjadi dasar sistem perancangan instruksional (Instructional System Design - ISD). Model ADDIE memiliki struktur yang tersusun secara sistematis, sehingga langkah dalam penelitian ini harus sesuai urutan dan tidak bisa di acak, berikut skema model ADDIE [7].

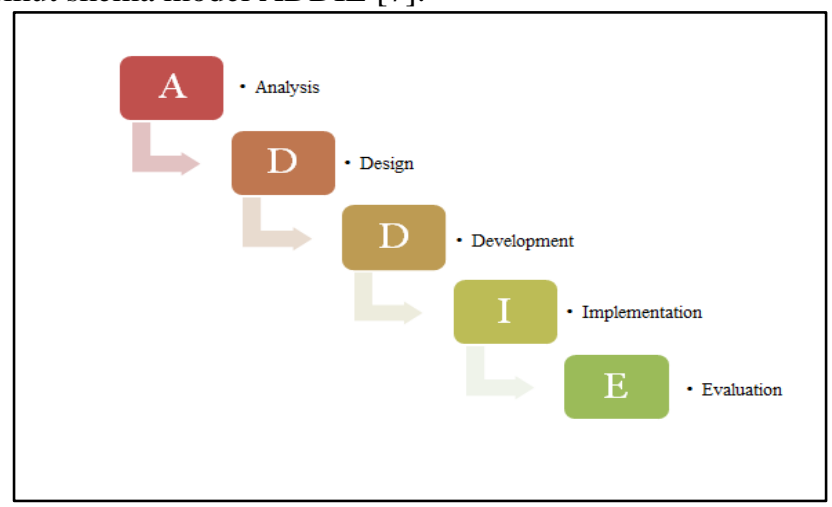

\section{Analysis (Analisis)}

Gambar 3.1 skema model ADDIE

Pada tahap analysis yang dibahas adalah Analisis kebutuhan pada tahap analisis ini meliputi pada pemilihan materi, penentuan pemakai (user), dan indikatornya.

\section{Design (Desain Produk)}

Desain produk merupakan suatu rancangan dari produk yang akan dibuat yang berfungsi untuk mempermudah pembuatan produk. Adapaun pembuatan produk diawali dengan menuliskan terlebih dahulu alur pembuatannya serta pemilihan aplikasi developer yang akan digunakan dalam pembuatan produk tersebut, supaya mudah untuk mencari file yang dibutuhkan, seperti file referensi, gambar maupun file pendukung lainnya, namun pada tahap ini akan memakan banyak waktu namun bila pada tahap design ini matang dan berhasil maka bisa menciptakan ide yang efisien dan praktis untuk lanjut ketahap berikutnya.

\section{Development (Pengembangan Produk)}

Tahap pembuatan produk aplikasi Kuis berbasis android ini didasarkan atas alur yang dibuat pada tahap sebelumnya. Pembuatan aplikasi Kuis menggunakan bantuan dari web pembuat aplikasi berbasis android yaitu Ispring suite 9.7, dengan design logo dan background menggunakan aplikasi picsart yang merupakan aplikasi editor gambar. Aplikasi Kuis ini dibuat dan disusun secara teratur sesuai urutan tertentu.

\section{Implementation (Penerapan)}

Tahap implementasi atau penerapan produk dilaksanakan dengan mengujicobakan produk yang telah dirancang kepada sejumlah responden, pada tahap ini memungkinkan setiap responden memberikan masukan terhadap aplikasi yang digunakan, penilaian responden terhadap aplikasi didasarkan atas indikator yang ditetapkan untuk menguji kelayakannya.

\section{Evaluation (Evaluasi)}

Evaluasi adalah proses untuk menganalisis media pada tahap implementasi. Tahap evaluasi ini mengacu pada data hasil penelitian dan dibahas sesuai indictaor penilaian yang telah di tentukan, masukkan saran beserta terhadap produk akan sangat dibutuhkan untuk evaluasi, dari tahap evaluasi tersebut maka akan muncul kesimpulan dan saran dari responden. 


\section{HASIL DAN PEMBAHASAN}

\section{A. Hasil Penelitian}

\section{Analysis (Analisis)}

a) Pemilihan Materi

Pada mata pelajaran Teknologi Informasi dan Komunikasi (TIK) Perlu adanya media pembelajaran interaktif, karena TIK merupakan mata pelajaran yang dibutuhkan menyesuaikan dengan kemajuan teknologi dari waktu ke waktu, juga terbatasnya buku modul belajar yang tersedia di sekolah. Materi yang di pilih yaitu pembahasan mengenai Microsoft office yaitu pengoperasian peangkat lunak pengolah angka atau yang sering disebut dengan Microsoft Excel.

b) Penentuan Pengguna (User)

Pada aplikasi kuis interaktif ini pengguna aplikasi di khusukan untuk kelas X, karena soal yang diambil dari materi mata pelajaran Teknologi Informasi dan Komunikasi (TIK) kelas X dan untuk membantu pengetahuan mendasar mengenai microsoft excel sejak dimulia dari kelas $\mathrm{X}$, namun tidak menutup kemungkinan bahwa aplikasi ini juga bisa saja dipakai oleh kelas XI dan kelas XII untuk mereview kembali mata pelajaran yang sudah dipelajari supaya mengingat kembali.

c) Indikator

Indikator pencapaian pada aplikasi ini adalah kelayakan aplikasi kuis interaktif sebagai media pembelajaran pada mata pelajaran Teknologi Informasi dan Komunikasi (TIK) untuk peserta didik kelas X di SMA Plus Nurul Ilmi, selain itu respon dari peserta didik dikatakan layak terhadap aplikasi kuis ini, ini berarti bahwa peserta didik begitu antusias dan cukup senang dengan aplikasi yang dibuat ini

\section{Design (Desain)}

a) Tahap Perancangan

Perancangan Pertama di mulai dengan membuka Microsoft Power Point untuk membuat design dan tampilan aplikasi di sesuaikan dengan story board yang telah di buat seperti pada gambar 4.1.

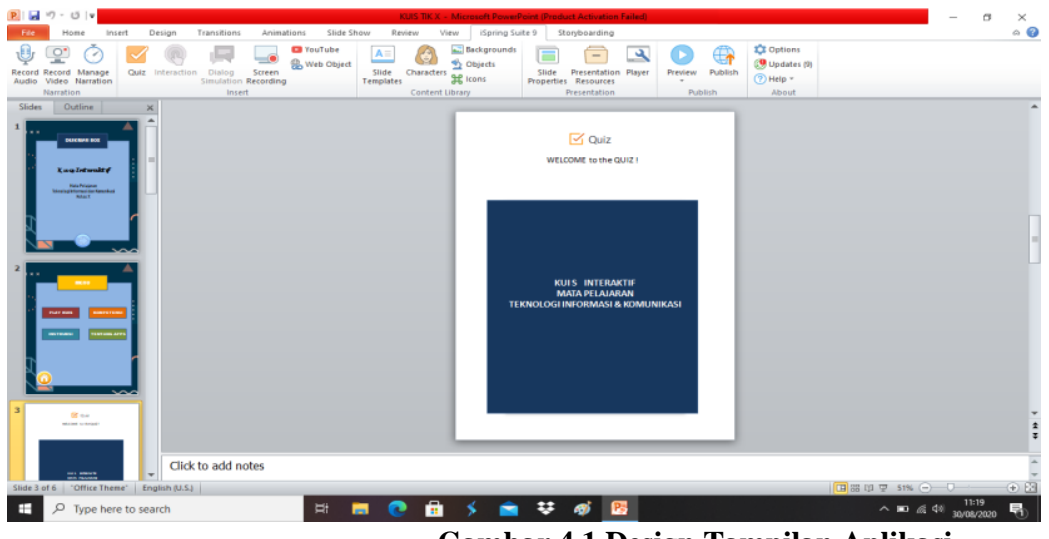

Gambar 4.1 Design Tampilan Aplikasi

Desain perancangan media pembelajaran kuis interaktif ini terdiri dari 2 content, content yang pertama yaitu kalimat opening sekaligus penegas dari aplikasi kuis tersebut dan content yang ke dua berisi menu yang terdiri dari menu Play Kuis, menu indikator, menu instruksi cara bermain, dan menu tentang Apps.

\section{Development (Pengembangan)}

Pembuatan aplikasi kuis interaktif ini menggunakan aplikasi Ispring Suit versi 9.7, aplikasi Ispring ini sudah terintegrasi dengan powerpoint dan memiliki tampilan yang tergolong user friendly dengan hasil akhir disimpan file berupa HTML document dengan format Horizontal dan menggunakan font Bauhaus 93 dan Forte 20 untuk Deskripsi box dan tulisan di awal sebagai opening, untuk penulisan soalnya menggunakan Times New Roman. 
Vol 5 No. 1 Edisi 2021

Setelah produk berhasil di kembangkan menuju ke langkah berikutnya yaitu dengan melakukan uji kelayakan media dengan cara uji kelayakan keseluruhan produk oleh 1 Ahli media.

\section{Implementation}

Di tahap implementasi pengujian produk dilaksanakan dengan mengisi kuesioner yang diberikan kepada ahli media, tenaga pendidik, juga peserta didik.

a) Hasil Uji Kelayakan Ahli Media

Tabel 4.1 Hasil Uji Kelayakan Ahli Media

\begin{tabular}{|c|l|c|}
\hline No & \multicolumn{1}{|c|}{ Aspek } & Skor di dapat \\
\hline 1 & Halaman Pembuka & 5 \\
\hline 2 & Halaman Utama & 25 \\
\hline 3 & Halaman Menu Play Kuis & 41 \\
\hline 4 & Halaman Menu Kompetensi & 10 \\
\hline 5 & Halaman Menu Instruksi & 10 \\
\hline 6 & Halaman Menu Tentang Apps & 10 \\
\hline 7 & Kejelasan Informasi & 34 \\
\hline Total & $\mathbf{1 3 5}$ \\
\hline Skor Maksimal & $\mathbf{1 7 0}$ \\
\hline Jumlah & $\mathbf{7 9 . 4 1 \%}$ \\
\hline Kriteria & Baik \\
\hline
\end{tabular}

Berdasarkan hasil instrument yang telah dinilai oleh ahli media dengan skor di dapat 135 kemudian dibagi skor maksimal 170 dikali 100\% maka mendapat hasil akhir 79,41\% Baik itu berarti aplikasi dinyatakan layak.

\section{b) Hasil Penilaian dari Tenaga pendidik}

Tabel 4.2 Hasil Penilaian dari Tenaga Pendidik

\begin{tabular}{|l|l|c|c|c|c|}
\hline \multirow{2}{*}{ No } & \multicolumn{1}{|c|}{ INDIKATOR } & \multicolumn{3}{c|}{ SKOR } \\
\cline { 3 - 6 } & & & & \\
TS/Y & $\%$ & HL & KRT \\
\hline 1 & Kesesuaian Soal dengan materi yang di ajarkan & $5 / 55$ & $100 \%$ & $90 \%$ & SB \\
\hline 2 & Memfasilitasi peserta didik dalam pembelajaran TIK & $4 / 55$ & $100 \%$ & $70 \%$ & B \\
\hline 3 & Kesesuaian dengan RPP dan Silabus di sekolah & $5 / 55$ & $100 \%$ & $90 \%$ & SB \\
\hline 4 & Keserasian warna & $4 / 55$ & $100 \%$ & $70 \%$ & B \\
\hline 5 & Keserasian jenis huruf (Font) & $4 / 55$ & $100 \%$ & $70 \%$ & B \\
\hline 6 & Kesesuaian tata letak tombol & $4 / 55$ & $100 \%$ & $70 \%$ & B \\
\hline 7 & Keteraturan sistematika penulisan & $5 / 55$ & $100 \%$ & $90 \%$ & SB \\
\hline 8 & Bahasa yang digunakan baik dan sesuai & $5 / 55$ & $100 \%$ & $90 \%$ & SB \\
\hline 9 & Secara keseluruhan aplikasi interaktif & $4 / 55$ & $100 \%$ & $70 \%$ & B \\
\hline 10 & Kemudahan dalam penggunaan navigasi pada menu utama & $5 / 55$ & $100 \%$ & $90 \%$ & SB \\
\hline 11 & Kemudahan dalam penggunaan media pembelajaran aplikasi & $4 / 55$ & $100 \%$ & $70 \%$ & B \\
\hline & kuis interaktif untuk media pembelajaran & & & & \\
\hline Persentase rata-rata soal & & $79,09 \%$ & \\
\hline Kriteria & & Baik \\
\hline
\end{tabular}

TS : : Total Skor yang didapat

Y : Skor maksimal

HL : Hasil (diambil dari total skor : Skor maksimal x 100)

KRT : Kriteria

Hasil Pneilaian dari tenaga pendidik diruntutkan satu persatu terlebih dahulu karena sample hanya 1 orang dan instrument hanya memiliki 11 pertanyaan, setelah di totalkan ke persentase pada bagiana HL (Hasil) dapat di lihat persentasenya, kemudian di rerata kan menggunakan rumus Ms. Excel yaitu Average untuk perhitungan rata-rata maka di dapat 79,09\% masuk kedalam kriteria baik dan dapat disimpulkan aplikasi layak digunakan. 
c) Respon dari Peserta didik

Tabel 4.3 Respon Peserta didik

\begin{tabular}{|c|l|c|c|c|c|}
\hline NO & \multicolumn{1}{|c|}{ ASPEK } & $\begin{array}{c}\text { SKOR } \\
\text { DIDAPAT }\end{array}$ & $\begin{array}{c}\text { SKOR } \\
\text { MAKSIMAL }\end{array}$ & JUMLAH & KRITERIA \\
\hline 1 & Kesesuaian Materi & 513 & 75 & $68,4 \%$ & Baik \\
\hline 2 & Desain & 531 & 75 & $70,8 \%$ & Baik \\
\hline 3 & Kemudahan penggunaan & 455 & 75 & $60,6 \%$ & Baik \\
\hline Persentase Rata-rata soal & \multicolumn{5}{|c|}{ Baik } \\
\hline Kriteria
\end{tabular}

Hasil dari respon peserta didik di bagi kedalam 3 Aspek, sampel peserta didik sebanyak 20 orang dan jumlah soal 15, skor yang di dapat dari aspek kesesuaian materi mendapat 513, Desain 531, kemudahan penggunaan 455 skor kemudian semuanya di bagi dengan skor maksimal yaitu 75 maka masing-masing dapat dilihat di tabel junlah untuk persentasenya kemudian di hitungkan persentase rata-rata yaitu $66,60 \%$ yang berarti baik dan aplikasi layak digunakan.

\section{Evaluation (Evaluasi)}

Evaluasi yang di dapat dari penilaian hasil produk berdasarkan tahapan implementasi, aplikasi kuis perlu untuk dievaluasi terhadap produk yang telah dikembangkan berdasarkan saran dari para peserta didik yang diberikan selama tahap implementasi. Hasil yang didapat adalah sebagian besar respon peserta didik memberi nilai baik dan sangat baik dilihat dari hasil angket yang telah diberikan sebelumnya, dari ahli media pun cukup baik, dan dari tenaga pendidikpun pun mendapat kriteria baik, berikut rinciannya :

a) Dari ahli media, kuesioner berjumlah 34 pertanyaan dan hasilnya produk mendapat skor 5 (Sangat baik) mendapatkan 17 pernyataan, skor 4 (baik) mendapatkan 5 pernyataan, skor 3 (cukup) mendapat 6 dan skor 2 (kurang) mendapatkan 6, total skor mendapat 135. Setelah dihitung menggunakan rumus yang telah di cantumkan di bab 3 bagian analisis data, secara keseluruhan mendapat nilai persentase $79,41 \%$ yang berarti baik, dimana rentang rerata skor kriteria baik adalah $60 \%-79,99 \%$, dan itu masuk kedalam kriteria Layak.

b) Dari tenaga pendidik, soal kuesioner berjumlah 11 dengan hasilnya produk mendapat skor 5 (sangat baik) mendapatkan 5 pernyataan, dan mendapat skor 4 (baik) adalah 6 pernyataan, dan ketika di hitung menggunakan rumus skala likert yaitu mendapatkan nilai persentase $79,09 \%$ yang berarti baik, diketahui bahwa penilaian skor kriteria baik adalah 60\% - 79,99\% dan itu masuk kedalam kriteria Layak.

c) Dari peserta didik soal berjumlah 15 dan sampelnya sebanyak 20 orang, ada 3 aspek yang dinilai yaitu kesesuaian materi, desain, dan kemudahan penggunaan, skor didapat dari aspek kesesuaian materi adalah 513 skor ketika di hitung menggunakan rumus mendapatkan nilai persentase 68,4\% yaitu kriteria baik rentang penilaian baik adalah 60\% - 79,99\%, dari aspek desain 531 skor dan ketika dihitung menggunakan rumus mendapatkan persentase $70,8 \%$ yang berarti kriteria baik dan dari kemudahan penggunaan adalah 355 skor ketika dihitung menggunakan rumus mendapatkan nilai persentase $47,3 \%$ yang berarti cukup baik dimana rentang penilaian cukup adalah $40 \%$ - 59,99\%.

\section{B. Pembahasan}

Aplikasi kuis ini dibuat sebagai media pembelajaran di SMA Plus Nurul Ilmi untuk alat bantu media belajar peserta didik dalam mata pelajaran Teknologi Informasi dan komunikasi, pada soal di aplikasi kuis ini yang di ambil adalah materi mengenai Microsoft excell, karena ini merupakan materi dasar di kelas X juga di perlukan di dunia kerja maupun di bangku perkuliahan, dengan adanya aplikasi kuis ini peserta didik bisa berlatih soal dirumah. Model yang di gunakan dalam penelitian ini adalah ADDIE yaitu Analysis, Design, Development, implementasi dan evaluasi, dan telah sesuai dilakukan sesuai runtutan ADDIE tersebut. Hasil yang didapat dari penelitian ini adalah bahwa di aplikasi Ispring suite bisa membuat aplikasi kuis berbasis android, peneliti menggunakan Ispring Suite versi 9.2 dengan kapasitas 64 bit. Media pembelajaran kuis ini membahas mengenai soal pada mata pelajaran Teknologi Informasi dan komunikasi, aplikasi ini merupakan aplikasi kuis interaktif berbasis android yang bisa digunakan oleh semua versi 
Vol 5 No. 1 Edisi 2021

android secara offline pada bagian kuis sudah terhubung dengan email maka ketika peserta didik mengerjakan soal dan sudah di tahap menampilkan nilai otomatis akan masuk ke email hasil jawaban dan rekapan nilai nya asalkan email yang digunakan masih dipakai.

Tabel 4.4 Diagram Persentase

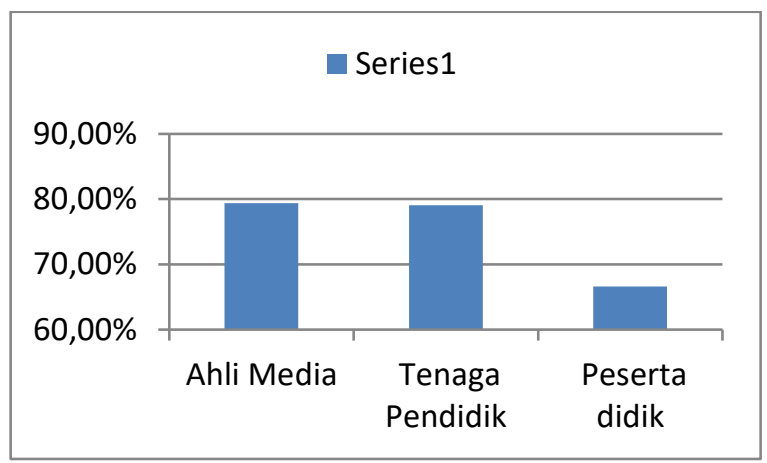

Aplikasi kuis ini diujikan kepada ahli media untuk menguji keLayakan nya, kepada tenaga pendidik selaku guru mata pelajaran TIK, juga kepada peserta didik untuk mengetahui respon peserta didik terhadap aplikasi yang dibuat. Berdasarkan penelitian penilaian Ahli media secara keseluruhan memperoleh 79,41\% dan dinyatakan layak, penilaian dari tenaga pendidik 79,07\% dinyatakan layak, dan dari peserta didik setelah di rerata kan skor mendapat $66,60 \%$ dinyatakan layak. Data yang di peroleh berupa data kualitatif yaitu hasil yang di dapat merupakan data lapangan. Wawancara, maupun observasi. Jadi aplikasi kuis interaktif ini layak untuk digunakan di kelas X SMA Plus Nurul Ilmi Cibalong.

\section{KESIMPULAN}

Dalam perancangan media pembelajaran kuis interaktif ini sudah melalui beberapa tahapan dari mulai tahap analisis sampai tahap evaluasi, maka dapat diambil kesimpulan yaitu :

1. Model penelitian yang digunakan dalam media pembelajaran aplikasi kuis interaktif ini adalah model ADDIE yaitu Analysis, Design, Development, Implementation dan evaluation.

2. Aplikasi kuis interaktif berbasis Android ini menggunakan sistem operasi Android versi 1.0 sampai dengan 9.0 pie.

3. Hasil yang didapat dari uji kelayakan oleh Ahli Media adalah sebesar $79,41 \%$, penilaian uji kelayakan yang dilakukan oleh tenaga pendidik mendapatkan nilai persentase sebesar $79,09 \%$ dan respon dari peserta didik terhadap kelayakan aplikasi mendapatkan nilai persentase $66,60 \%$ yang berarti kriteria baik

4. Media Pembelajaran Kuis interaktif pada mata pelajaran Teknologi informasi dan komunikasi berbasis android ini Layak dan dapat digunakan oleh pengguna sebagai media pembelajaran interaktif pada mata pelajaran Teknologi Informasi \& Komunikasi.

\section{DAFTAR PUSTAKA}

[1] Anrianto, M Y, Syahroni, Kuis Islam berbasis android 2013, jurnal : Universitas Muhammadiyah Sidoarjo

[2] Arsyad, A. (2007). Media Pembelajaran, Jakarta: Rajagrafindo Persada

[3] Darmadi, Hamid.2011. Metode Penelitian Pendidikan.Penerbit Alfabeta.Bandung.

[4] Firly Nadia.2019. Create Your Own Android Application.Penerbit PT Elex Media Komputindo,Jakarta

[5] Herlinah, Musliadi.2019. Pemrograman Aplikasi Android dengan Android Stusio, Photoshop, dan Audition. Penerbit PT Elex Media Komputindo,Jakarta

[6] National Education Association,1969. Audiovisual Instruction Departmen, New Media And College Teaching, Washington D.C. : NEA.

[7] Peterson, C. (2003). Bringing ADDIE to Life: Instructional Design at its best. Journal Of Educational Multimedia and Hypermedia, Vol 12(3),227-241.

[8] Sugiyono. 2016. Metode Penelitian Pendidikan Pendekatan Kuantitatif, Kualitatif, dan $R$ \& D. Penerbit Alfabeta,Bandung.

[9] Suryadi, Ace.2007. Pemanfaatan ICT dalam Pembelajaran Universitas Krisna, dipayana. Jurnal Pendidikan Terbuka dan Jarak Jauh. Vol 8. No 1.83-98. 


\section{BIODATA PENULIS}

Rosi Aprilia Utami, memperoleh gelar Sarjana Pendidikan (S.Pd), Program Studi Pendidikan Teknologi Informasi FKIP Universitas Muhammadiyah Tasikmalaya, lulus tahun 2020.

Cecep Riki, memperoleh gelar Sarjana Teknik (S.T), Program Studi Teknik Informatika STMIK DCI, lulus tahun 2007. Pada tahun 2011 memperoleh gelar Magister Manajemen Komputer (M.MKom) dari jurusan Manajemen Komputer di STM IMNI Jakarta. Saat ini sebagai Staf Pengajar Program Pendidikan Teknologi Informasi Universitas Muhammadiyah Tasikmalaya (UMTAS).

Alfadl Habibie, memperoleh gelar Sarjana Pendidikan (S.Pd). Saat ini sebagai Staf Pengajar Program Pendidikan Teknologi Informasi Universitas Muhammadiyah (UMTAS). 